\title{
The Properties of Trichloracetic Acid-Ethanol Extracts of Human Plasma
}

\section{Physical, chemical and immunological properties of the extracts}

\author{
J.S. Cameron, D.R. Boyns, R.J. Jarrett and H. KeEN
}

Department of Medicine, Guy's Hospital, London.

Received February 28, 1966

Summary. The insulin-like activity (ILA) of T.C.A.ethanol extracts, prepared from the plasma of normal subjects was compared with that of crystalline insulin. Dose-response curves were obtained for the glucose uptake and ${ }^{14} \mathrm{C}$-glucose incorporation into lipid of the epididymal fat pad and the glucose uptake of the rat hemidiaphragm. For each of these, the dose-response relationship of the ILA of the extract approximated to that of crystalline insulin. The stimulation of ${ }^{14} \mathrm{C}$-glucose incorporation into lipid by the extracts and by crystalline insulin was suppressed by $10^{-4} \mathrm{M}$ n-ethylmaleimide. Antiserum to ox-insulin from guinea pigs, which completely suppressed the effect of human and bovine crystalline insulin, had no effect upon the ILA of eight extracts and induced a small, but statistically significant reduction in the ILA of four extracts. - Studies were also performed, using gel filtration by sephadex G. 200, on extracts prepared from the plasma of both normal and diabetic individuals, and upon three pooled T.C.A.-ethanol extracts. In each case, the extract showed two peaks of elution of protein, the second being identical with that of ${ }^{125}$ I-labelled human albumin. The first peak corresponded to an apparent molecular weight of 300000-1000000. Despite the difference in molecular weight, the properties of the two eluates were similar when compared by electrophoresis and by immuno-electrophoresis. Assay of the column eluate showed that both non-suppressible ILA and immunoreactive insulin were present throughout the whole range of elution. - The findings are discussed with reference to the phenomenon of insulin-like activity and of synalbumin antagonism.

Les propriétés d' extraits de plasma humain par l'acide trichloracétique-éthanol 2. Propriétés physiques, chimiques et immunologiques des extraits.

Résumé. I'activité insulinique (insulin-like activity: ILA) d'extraits par l'acide trichloracétique (T.C.A.)éthanol, préparés à partir de plasma de sujets normaux, a été comparée à celle de l'insuline cristalline. Les courbes dose-effet ont été obtenues pour la captation du glucose et l'incorporation de ${ }^{14} \mathrm{C}$-glucose dans les lipides $\mathrm{du}$ tissu adipeux de l'épididyme, et pour la captation du glucose par l'hémidiaphragme du rat. Pour chacun de ces tests la relation dose-effet de I'ILA de l'extrait était voisine de celle de l'insuline cristalline. La stimulation de l'incorporation du ${ }^{14} \mathrm{C}$-glucose dans les lipides par les extraits et par l'insuline cristalline était supprimée par la n-éthylmaléimide $10^{-4} \mathrm{M}$. Le sérum de cobaye anti-insuline bovine, qui supprimait complètement l'effet de l'insuline cristalline humaine et bovine, n'a pas eu d'effet sur l'ILA de huit extraits et a produit pour quatre extraits une réduction de I'ILA légère mais statistiquement significative. - Des études ont été aussi réalisées en utilisant la filtration sur gel de Sephadex G 200, sur des extraits préparés à partir de plasma à la fois de sujets normaux et diabétiques et sur trois "pools» d'extraits par le T.C.A.éthanol. Dans chaque cas, l'extrait a montré deux pics d'élution de protéine, le second étant identique à celui de l'albumine humaine marquée à l'125T. Le premier pic correspondait à un poids moléculaire apparent de $300000-$ 1000000 . En dépit de la différence de puids moléculaire, les propriétés des deux éluats étaient semblables quand on les a comparées par électrophorèse et par immunoélectrophorèse. Un dosage de l'éluat de la colonne a montré que, à la fois, I'ILA non-supprimable et l'insuline immuno-réactive étaient présentes dans toutes les fractions de l'élution. Les résultats sont discutés en se référant au phénomène de l'activité insulinique et de l'antagonisme par synalbumine.

Die Eigenschaften von Trichloressigsäure-ÄthylalkoholExtrakten des menschlichen Plasmas. 2. Physikalische, chemische und immunologische Eigenschaften der Extrakte.

Zusammenfassung. Die insulinähnliche Aktivität (ILA) von aus dem Plasma von Normalpersonen gewonnenen Trichloressigsäure-Äthylalkohol-Extrakten und von kristallinem Insulin wurde miteinander verglichen. Es ließen sich Dosis-Wirkungskurven für die Glucoseaufnahme und die Einlagerung von ${ }^{14} \mathrm{C}$-Glucose in das Fett des epididymalen Fettgewebes und für die Glucoseaufnahme des Hemidiaphragmas der Ratte aufstellen. Für jede dieser Reaktionen war die Beziehung Dosis - Wirkung der ILA der Extrakte annähernd gleich der des kristallinen Insulins. Die Steigerung der ${ }^{14} \mathrm{C}$-Glucose-Einlagerung in Fett durch die Extrakte und durch kristallines Insulin wurde durch $10^{-4} \mathrm{M}$ n-Äthylmaleimid unterdrückt. Antirinderinsulinserum vom Meerschweinchen, das die Wirkung von menschlichem und kristallinem Rinderinsulin vollständig hemmte, hatte auf die ILA von acht Extrakten. zeinen Effekt und führte bei 4 Extrakten zu einem kleinen doch statistisch gesicherten Abfall der ILA. Unter Benutzung der Gelfiltration durch Sephadex 200 wurden weitere Versuche mit Extrakten aus dem Plasma normaler und diabetischer Menschen und mit drei "gepoolten" Trichloressigsäure-Alkohol-Extrakten durchgeführt. In allen Fällen zeigte der Extrakt zwoi Eiweißelutionsgipfel, wobei der zweite mit dem Giofel des $125 \mathrm{~J}$ markierten menschlichen Albumins identisch war. Der erste Gipfel entsprach einem augenscheinlichen Molekulargewicht von 300000 1000000. Trotz des Unterschiedes im Molekulargewicht waren die Eigenschaften der beiden Eluate beim Vergleich in der Elektrophorese und Tmmunelektrophorese ähnlich. Die Insulinbestimmung des Säulen-Eluats zeigte, daß die nichthemmbare ILA und das immunologisch aktive Insulin über den gesamten Elutionsbereich vorhanden waren. - Die Ergebnisse werden in bozug auf das Phänomen der insulinähnlichen Aktivität und des Svnalbuminantagonisten besprochen. 
In previous reports (KeEN, 1963; CAMERoN, KEEN and Menzinger, 1964) and in the accompanying paper we have described the properties of trichloracetic acidethanol (TCA-ethanol) extracts of human plasma with regard to their content of immunoassayable and biologically assayable insulin. This paper reports the behaviour of TCA-ethanol extracts of human plasma on passage through Sephadex G 200 gel, the properties of the fractionated extracts and the relationship between the insulin-like activity (ILA) in the extracts and crystalline insulin.

\section{Materials and Methods}

Plasma extracts. The extracts prepared from the plasma of newly diagnosed diabetics and the three pooled extracts prepared by Dr. W.L. AsнтоN were described in the accompanying paper. Extracts were also prepared from the plasma of twelve normal subjects, ranging in age from 19 to 38 years. The venous samples from these subjects, who were fasted overnight, were taken into heparinized tubes, and the plasma immediately separated by centrifugation and stored frozen until used. TCA-ethanol extracts were later prepared by the method of Desio et al. (1957), as described by VALLANCE-OwEN et al. (1958).

Insulin antiserum. Antiserum to crystalline bovine insulin was prepared in guinea pigs by the method of RoBINSON and WRIGHT (1961). $0.1 \mathrm{ml}$ of a $1 / 10$ dilution of this antiserum completely suppressed the stimulation of glucose uptake of the rat epididymal fat pad by $20 \mathrm{mU}$ of crystalline human or bovine insulin in volumes of medium up to $2.0 \mathrm{ml}$.

Incorporation of radioactivity from glucose- $U-{ }^{14} C$ into tissue lipid. Both glucose uptake and glucose incorporation into lipid were measured in each unit of tissue by the following method. At the end of incubation in $0.25 \mathrm{ml}$ of medium, containing $0.125 \mu \mathrm{C}$ of glucose-U. ${ }^{14} \mathrm{C}$ per $\mathrm{ml}, 1.0 \mathrm{ml} 1 \%$ potassium fluoride was added. After mixing, the tissue was removed, rinsed twice in saline and then ground, using a motor-driven Potter homogenizer, in $3.0 \mathrm{ml}$ of an extraction mixture (DoLE, 1956) containing isopropyl alcohol: heptane: $1 \mathrm{~N} \mathrm{H}_{2} \mathrm{SO}_{4}$ (40:10:1 parts by volume). $3 \mathrm{ml}$ heptane and $2 \mathrm{ml}$ water were added to the homogenate, the mixture shaken for two minutes and, after standing overnight, $1 \mathrm{ml}$ aliquots of the upper, heptane, phase were added to $6 \mathrm{ml}$ dioxane phosphor, containing dioxane: xylene: ethyl alcohol (39:39:23 parts by volume) and diphenyloxazole $(0.5 \mathrm{~g})$, and counted in a liquid scintillation counter. After removal of the tissue, the glucose concentration of the medium was estimated in an Autoanalyser and the glucose uptake of the tissue calculated from the fall in concentration during the incubation.

Sephadex gel filtration of the extracts was carried out at room temperature on a $70 \times 2 \mathrm{~cm}$ column of G. 200 Sephadex, in "tris" buffer ( $\mathrm{pH} 7.4, \mathrm{I}=0.05$ ) using an LKB fraction collector to obtain $3.0 \mathrm{ml}$ samples. The protein concentration of the samples was estimated by the spectrophotometric method of WADDELL (1956). ${ }^{125} \mathrm{I}$ and ${ }^{131} \mathrm{I}$ radioactivity were measured. in a well-type scintillation counter.

Gel immunoelectrophoresis was performed by the technique of SoHEIDEGGER (1955) using commercially prepared antiserum, obtained from Baxter Laboratories, Ltd., Human albumin (Lister Institute) was iodinated with ${ }^{125} \mathrm{I}$ by the method of MACFARLANE (1958). All other methods are detailed in the accompanying paper.

\section{Results}

Comparison of extract-ILA and crystalline insulin. The dose-response relationship of erystalline human insulin on the isolated rat epididymal fat pad was compared with that of the extract-ILA, prepared from the plasma of two normal subjects. With extracts from the plasma of a further eight normal subjects, similar comparisons were made with crystalline bovine insulin. The lines were approximately parallel for both glucose uptake (Fig. 1) and the incorporation of radioactive

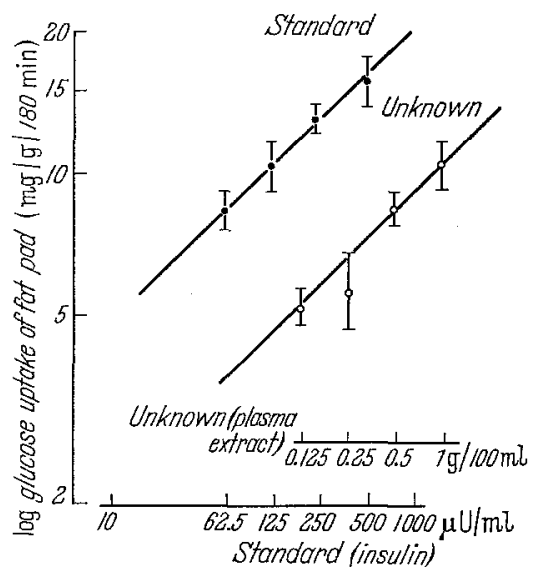

Fig. 1. The dose-response for crystalline human insulin and the ILA in plasma TCA-ethanol extracts. Assayed by glucose uptake of fat (mg/g/180 minutes) using an epididymal fat microincubation method

carbon into lipid. Similar parallelism was also obtained with the glucose uptake of the rat hemidiaphragm as a measure of activity.

The effect of $10^{-4} \mathrm{M}$ n-ethylmaleimide (NEM) on the assay of the extract-ILA by the fat pad was examined (Fig. 2). NEM completely suppressed the stimulating effects of both erystalline bovine insulin and the extract-ILA upon incorporation of radioactivity from glucose-U. ${ }^{14} \mathrm{C}$ into lipid. However, contrary to the findings of Mirsky and Perisutti (1962), NEM at this concentration also depressed basal incorporation of glucose into lipid.

The influence of antiserum to ox insulin from the guinea pig on extract-ILA was studied in extracts from the twelve normal subjects. Both glucose uptake 
(Fig. 3) and incorporation of radioactivity from ${ }^{14} \mathrm{C}$ glucose into lipid (Fig. 4) of the epididymal fat pad.

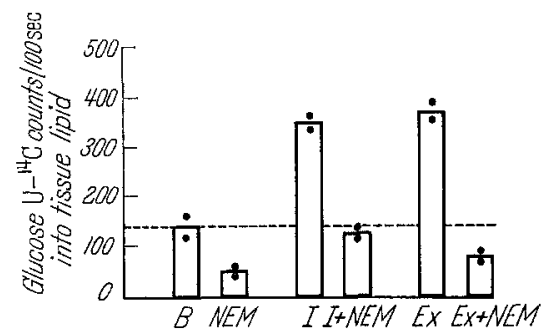

Fig. 2. The effect of $10^{-4} \mathrm{M}$ n-ethylmaleimide (NEM) upon the incorporation of radioactivity from glucose- $\mathrm{U}^{14} \mathrm{C}$ into lipid of rat epididymal fat in buffer (B), buffer + crystalline bovine insulin (I) and buffer + TCA-ethanol extract (Ex). The histograms represent the means and the standard error of the means of observations on four pieces of fat

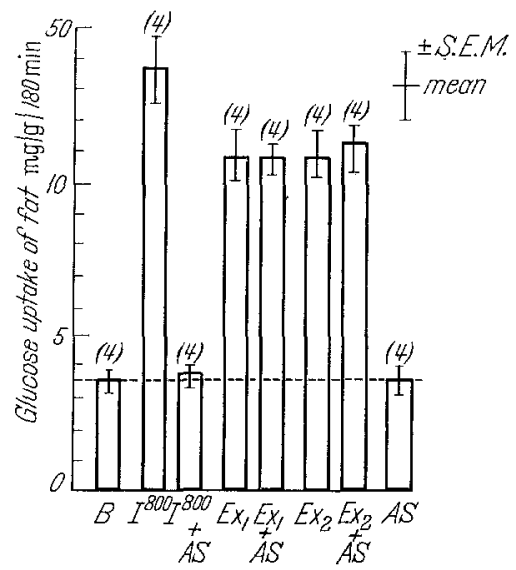

Fiw. 3. Glucose uptake of rat epididymal fat. Stimulation by an insulin standard $(800 \mu \mathrm{U} / \mathrm{ml})$ and two extracts $\left(\mathbf{E x}_{1}\right.$ and $\left.\mathbf{E x}_{2}\right)$ in the presence and absence of insulin antiserum (AS). Each figure is the mean of observations on four pieces of fat.

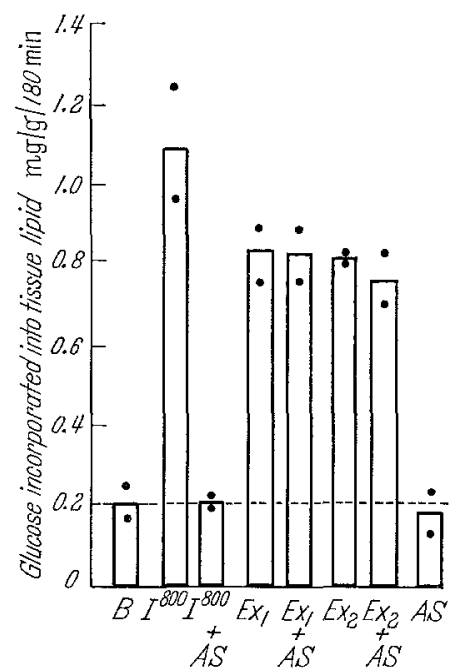

Fig. 4. Glucose incorporation into lipid of rat epididvmal fat, by the same extracts as in Fig. 3. The histograms represent the means and the standard error of the means of two estimations on paired pieces of fat. The glucose incorporation was calculated from the specific activity of glucose- $\mathrm{U}-{ }^{14} \mathrm{C}$ in the incubation medium and the radioactivity present in tissue lipid after 180 minutes incubation were measured. Four extracts showed small but statistically significant $(p<0.05$ ) reductions in ILA in the presence of antiserum. The other eight extracts showed no significant reductions in their ILA. Insulin antiserum similarly failed to suppress the effects of the extracts upon glucose uptake (Fig. 5) or glycogen deposition in the hemidiaphragm (Fig. 6).

Gel filtration. Studies were made on extracts prepared from both normal and diabetic plasma and on the three pooled extracts (Fig. 7). In each case the

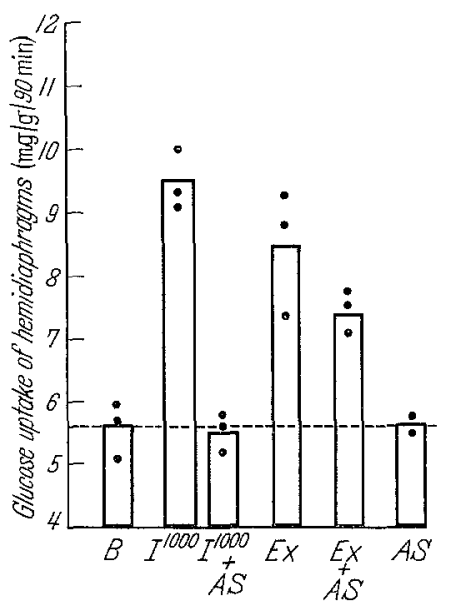

Fig. 5. Glucose uptake of rat hemidiaphragm. The effects of crystalline bovine insulin $(1000 \mu \mathrm{U} / \mathrm{ml})$ and an extract (Ex) are shown, with and without insulin antiserum. Each figure represents the mean of three observations

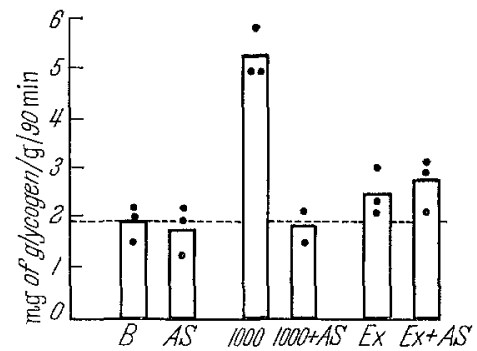

Fig. 6. Glyeogen deposition in rat hemidiaphragm. Same experiment as that shown in Fig. 5 .

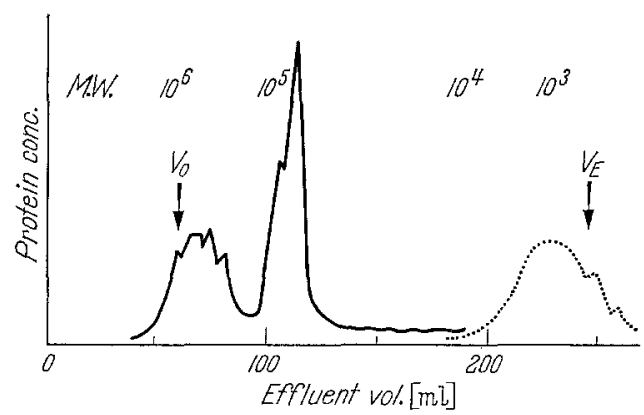

Fig. 7. The pattern of protein concentration in a TCA-ethanol extract chromatographed on a sephadex G. 200 column. The corresponding mole cular weights (M.W.) are indicated above. The dotted lines represents the elution pattern of ${ }^{151} \mathrm{I}$-iodoinsulin added as a marker 
extract showed two fairly well defined peaks of elution of protein, the second being identical with that of ${ }^{125}$ I-labelled human albumin added as a marker. The first peak corresponded to an apparent molecular weight of $300000-1000000$. Despite the considerable difference in apparent molecular weight between the two peaks, their properties were closely similar when they were compared by electrophoresis and by immunoelectrophoresis (Fig. 8).

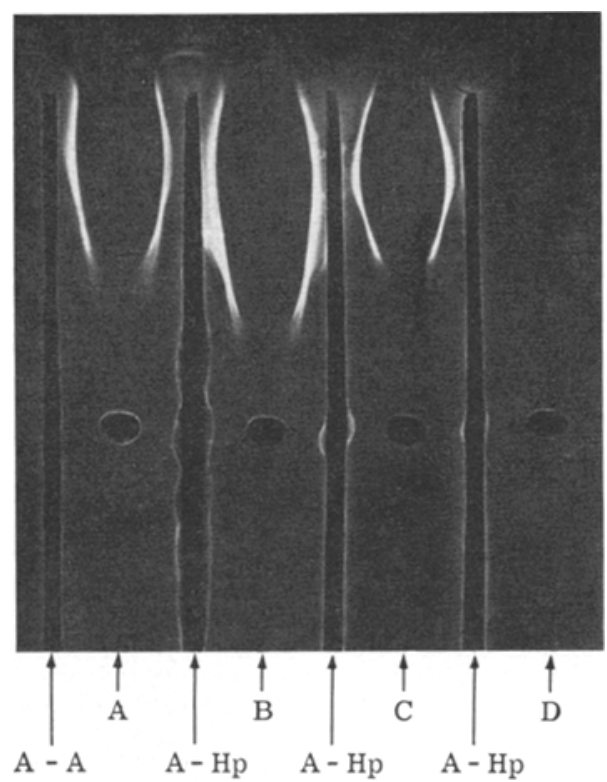

Fig. 8. Gel immunoelectrophoresis of sephadex $G$. 200 fractions derived from a TCA-ethanol extract of plasma. $A$ is the large molecular weight first peak; $\mathrm{B}$ and $\mathrm{C}$ are fractions derived from the true albumin peak; $\mathrm{D}$ is the low molecular weight $(50000-3000)$ fraction. $A-A$ is an antiserum to human crystalline albumin and $\mathrm{A}-\mathrm{Hp}$ is an antiserum to human plasma, both raised in rabbits

In two experiments, using extracts from the plasma of normal subjects, the column eluate was separated into four fractions $(A-D)$, which were then dialysed

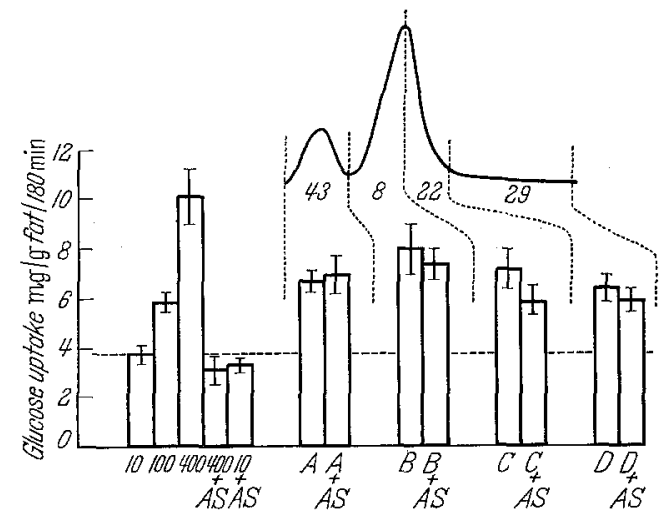

Fig. 9. Adipose tissue assay (glucose uptake) of fractions $\mathbf{A}-\mathbf{D}$ from the Sephadex G. 200 column (see text). The histograms show the effects of crystalline insulin standards and the extract fractions, with and without insulin antiserum (AS). The results are the mean \pm S.E.M. of four observations. The figure above are the results of immunoassay of the same fractions $(\mu \mathrm{U} / \mathrm{ml})$ against distilled water and freeze dried. Each fraction was later subjected to immunoassay, and bioassay on the fat pad where suppression by insulin antiserum was also tested. Both immunoreactive insulin (IRI) and non-suppressible ILA were present in all fractions, including the large molecular weight peak designated $\mathbf{A}$ (Fig. 9).

\section{Discussion}

Extraction procedures based on the use of acidethanol, selectively extract material with the properties of crystalline insulin (ScotT and Fisher, 1938). Our procedure, a TCA-ethanol extraction applied to both normal and diabetic plasmas, succeeds in extracting material with insulin-like properties. In this it is similar to other plasma extractions based upon acid-ethanol treatment (FroEsCH et al., 1964; DAvidson et al., 1963) and like these, also gives high values for plasma insulin content. Our extracts, however, like those of Froesch et al. (1964) are only partially inactivated by the addition of potent anti-insulin serum that demonstrably neutralises completely the activity of crystalline insulin. This is reflected by the low levels of immunoassayable insulin in our extracts.

Assuming that only a small part of the extract-ILA represents "crystalline" insulin - that part measurable by immunoassay - there remains the problem of the identity of the remaining activity. Two major possibilities exist; firstly, that it is due to insulin in a form that is not identifiable immunologically, and secondly, that it is due to some other plasma constituent rendered insulin-like by the extraction procedure. In considering the first possibility, it may be relevant that the pattern of elution of the albumin from the Sephadex column suggested changes in its molecular size, perhaps as a result of the extraction process. This phenomenon was also noted by Ais and RECANT (1965) in their extracts, using starch gel electrophoresis. Similarly, aggregation of insulin molecules might account for the wide range of molecular weight fractions in which the ILA was eluted. Alternatively, the elution pattern of the ILA might have resulted from some physical association between the albumin and insulin. This would seem more probable in that IRI was also found in a wide range of molecular weight fractions.

These results with gel filtration suggest that the unit molecular weight of the ILA may be low and similar to that of the IRI. Together with the almost identical behaviour of the ILA and crystalline insulin in several different situations in vitro, they support the view that the ILA is a function of an altered insulin molecule. The behaviour and properties of our extract-ILA is very similar to that reported by BÜRGI et al. (1965) for their nonsuppressible ILA (NSILA) prepared from plasma by a slightly different acidethanol extraction. These authors demonstrated that, under suitable conditions, their high molecular weight ILA could be dissociated into units of molecular weight 
approximating to that of crystalline insulin. It is very likely, therefore, that our extract-ILA is the same as the NSILA of BÜRGI et al. (1965).

We have no experimental evidence concerning the second possibility - that the ILA somehow arises as a result of the extraction process. However, it remains a possibility justifying further experiment.

KIPNIS and STEIN (1964) have suggested yet another explanation of plasma NSILA - that it is a function of albumin itself. However this explanation could not account for our data. Fraction D of the Sephadex G. 200 eluate contained not more than $0.1 \mathrm{mg} / 100 \mathrm{ml}$ albumin but, nevertheless, contained considerable NSILA (Fig. 9).

JERveLL (1965) has recently reviewed the T.C.A.ethanol extraction procedure and has come to the conclusion that it extracted albumin, insulin and an insulin antagonist from plasma. He also suggested that different results obtained with the extracts by different workers are probably explicable by small differences in the procedure, which alter the relative amounts of insulin and insulin antagonist, a suggestion similar to one made by CaMeron et al. (1964). However this explanation is now untenable in view of the conflicting results obtained by AsHToN (1965) and ourselves using identical extracts. Attention now has to be directed to the technique of the hemidiaphragm incubation itself. In this context, the properties of the albumin itself may be relevant. Thus it has long been known that albumin can bind metallic ions (ALBERT, 1961; CARR, 1955) and also that the action of insulin upon the diaphragm and the fat pad in vitro is affected by both the absolute and the relative amounts of certain metal ions in the medium (BHatTacharya, 1961; MERTz et al., 1961). Certainly the chelating agent, sodium ED$\mathrm{TA}$, in a concentration of $10^{-2} \mathrm{M}$, abolishes the effect of insulin upon glucose uptake of the rat hemidiaphragm, but it has no effect upon insulin stimulation. of glucose uptake by rat epididymal fat (RIHAN et al., 1965).

Acknowledgments. We are grateful to Dr. W.L. AsHTon for allowing us to examine his extracts, to Mr. N. VEALI for labelling the human albumin and to DR. P.H. WRIGHT for a gift of insulin antiserum. Technical assistance was provided by Messis. N. Garns, M. MrLter-Jones and L. Yeura. This work was partly supported by grant No. AM 6135 MET from the National Institute of Health, Bethesda, U.S.A. and by assistance from the British Diabetic Association.

\section{References}

AtBerit, A.: Design of chelating agents for selected biological activity. Fed. Proc. 20 (3). Suppl. 10, 137-147 (1961).

ALP, H., and L. RECANT : Studies of the insulin-inhibitory effect of human albumin fractions. J. clin. Invest. 44, $870-882(1965)$.

Ashton, W.L.: The glucose uptake induced in rat hemidiaphragms by insulin in the presence of human albumin. J. Endocr. 33, 103-107 (1965).
BHATTACHARYA, G.: Effects of metal ions on the utilisation of glucose and the influence of insulin on it by the isolated rat diaphragm. Biochem. J. 79, 369-377 (1961).

Bürgi, H., W.A. Müller, R.E. HuMrex and E.R. Froesch: Purification of a plasma protein with nonsuppressible insulin-like activity. Communication to 1st Meeting of European Association for the Study of Diabetes, Montecatini, April, 1965.

CAMERON, J.S., D.R. BOYNS, R.J. JARRETT and K. KEEN : The properties of trichloracetic acid-ethanol extracts of human plasma (1). Diabetologia. 2, 86-90 (1966)

Cameron, J.S., H. Keen and G. Menzinger: Insulin activity of normal plasma and plasma acid-ethanol extracts. Lancet $\mathbf{1 9 6 4} \mathrm{I}, 74-76$.

CARR, C. W.: Competitive binding of calcium and magnesium with serum albumin. Proc. Soc. exp. Biol., N.Y., $89,546-549(1955)$.

Davidson, J.K., R.E. HaIst and C.H. Best: Studies employing a new method for the recovery of biologically active insulin from acid alcoholic extracts of pancreas and blood serum. Diabetes 12, 448-453 (1963).

Debro, J.R., H.E. Tarver and A. Korner: The determination of serum albumin and globulin by a new method. J. Lab. clin. Med. 50, 728 -732 (1957).

DOLE, V.P.: Relation between non-esterified fatty acids in plasma and metabolism of glucose. J. clin. Invest. $35,150-154(1956)$.

Froksch, E.R., H. Bürgi, W.A. MüLler and A. LABHART: Mit antiinsulinserum hemmbare und nichthemmbare insulinactivität im menschlichen serum. Schweiz, med. Wschr. 94, 309-413 (1964).

JERVELL, J.: The antagonistic effect of human plasma albumin on the insulin stimulated glucose uptake of the isolated rat diaphragm. Acta physiol. scand. 65, $33-44(1965)$.

KEEN H.: Properties of human albumin. A metabolic study of albumin extracts from normal and diabetic plasma. Diabetes 12, $406-413$ (1963).

KIPNIS, D.M., and M.F. STEIN : Insulin antagonism; fundamental considerations. Ciba Foundation Colloquium on Endocrinology, Vol. 15, pp. 156-184 (1964).

MaCFARLANE, A.S.: Efficient trace-labelling of proteins with iodine. Nature 182, 53 (1958).

Mertz, W., E.E. Rogrnsti and K. Souwarz: Effects of trivalent chromium complexes on glucose uptake by epididymal fat tissue of rats. J. biol. Chem. 236, 318322 (1961).

MIrsky, I.A., and G. Pertsutut The inhibition of the action of insulin on rat epididymal adipose tissue by sulfhydryl blocking agents. Biochim. biophys. Acta 62, $490-496$ (1962)

Rihan, Z., C. Chuouverakis, R. J. JarretT and H. KeEN : EDTA and insulin action. Communication to the Medical and Scientific Section of the British Diabetic Association, Oct. 1965.

RobINSON, B.H.B., and P.H. WRTGHT: Guinea pig antiinsulin serum. J. Physiol. 155, 302-310 (1961).

ScheIDEGGER, J.J.: Une micro-méthode de l'immunoélectrophorèse. Arch. Int. Allergy, 7, $103-110$ (1955).

Scotr, D.A., and A.M. Frster: Studies of the pancreas and liver of normal and zine-fed cats. Amer. J. Physiol. 121, 253-260 (1938).

VALLANCE-OWEn, J., E. Denneas and P.N. CAMpbelil: Insulin antagonism in plasma of diabetic patients and normal subjects. Lancet 1958 II, 336-338.

WADDELL, W.J.: A simple ultraviolet spectrophotometric method for the determination of protein. J. Lab. clin. Med. 48, 311-314 (1956).

\author{
J.S. CAMERoN \\ Department of Medicine \\ Guy's Hospital \\ London/England
}

